\title{
Electronic Civil Disobedience and Symbolic Power
}

\section{Graham Meikle}

\section{Introduction}

In May 2005, a small group of online activists called the Electronic

Disturbance Theater staged a virtual sit-in. Their target was the website of the Minutemen Project, a vigilante organization which opposes immigration to the US, particularly from Mexico and Latin America. From 27 to 29 May, a claimed 78,500 people joined an online swarm that aimed to disrupt access to the Minutemen's website as a symbolic gesture of opposition, analogous to a physical sit-in at the organization's premises (Dominguez 2005, Kartenberg 2005, Jordan 2007). Such actions illustrate the practice of 'electronic civil disobedience' (ECD). The practice of ECD has been established since the mid1990s and certain key characteristics have emerged — actions are publicised in advance in order to draw as many participants as possible; actions do not cause damage to the targeted site, but merely simulate a sit-in; actors are open about their goals and identities.

ECD is a key example of the Net's capacity to enable users to exercise what Castells terms 'counter-power' — 'the capacity by social actors to challenge and eventually change the power relations institutionalized in society' (2007: 248). However, the discourse of ECD is contested, and where its proponents seek to align it with the civil disobedience tradition of Thoreau, Gandhi and 
Martin Luther King, it is frequently implicated in other discourses: in the concept of 'hacktivism' (e.g. Jordan 2002, 2007; Vegh 2003; Jordan \& Taylor 2004); in the concept of 'netwar' (e.g. Arquilla \& Ronfeldt 1997, 2001a, 2001b, 2001c; Arquilla 1998; Arquilla et al 1998); and in debates about terrorism (e.g. Denning 2000, 2001a, 2001b; Manion \& Goodrum 2000; Margolis \& Resnick 2000; Hoffman 2006).

In an information society, suggests Melucci, 'the power of information is essentially the power of naming' (Melucci 1996: 228, emphasis in original). The contested term 'electronic civil disobedience' and its imbrication with other discourses of hacking and hacktivism, of netwar and terrorism, is, in Melucci's terms, 'a conflict of nomination, conflict over the meaning of words and things in a society in which the name to an increasing degree supplants reality $[\ldots]$ in today's information society, the manner in which we nominate things at once decides their very existence' (Melucci 1996: 161, emphasis in original). This chapter suggests that ECD can be better understood and distinguished from competing discourses by viewing it in terms of symbolic power (Bourdieu 1991, Thompson 1995, Couldry 2000, 2003). The chapter first expands upon the concept of symbolic power, before sketching the history of ECD. It then discusses, in turn, the distinctions between ECD and hacktivism, netwar and terrorism.

\section{Symbolic Power}

The mediascape is, as Castells argues, 'the social space where power is decided' (2007: 238). The media enable an arena for the defining of reality. 
James Carey once argued that reality is 'a scarce resource' (1989: 87). In this, the ability to define reality is also, as Carey puts it, a 'fundamental form of power' (p. 87). This 'fundamental form of power' is what Bourdieu calls 'symbolic power' — 'Symbolic power is a power of constructing reality' (1991: 166). This is the ability 'to intervene in the course of events, to influence the actions of others and indeed to create events, by means of the production and transmission of symbolic forms' (Thompson 1995: 17). Thompson distinguishes symbolic power from other dimensions of power - the coercive power of the military or the law, the political power of governments, and the economic power of corporations. Coercive power works through the use or threat of force; political power through the coordination and regulation of individuals and groups; economic power through productive activity, the creation of raw material, services and goods, and financial capital (1995: 1218).

Symbolic power grows out of 'the activity of producing, transmitting and receiving meaningful symbolic forms' (Thompson 1995: 16). Such symbolic forms would include ideas and images, stories and songs, information and entertainment. They would also, of course, include activist communications, media interventions, and online campaigning. Symbolic power, as Bourdieu put it in defining the concept that Thompson develops, is the power of 'making people see and believe' (1991: 170). It is the power to name, to define, to endorse, to persuade. Institutions such as the media, universities, schools, government and religious organizations are all in the symbolic power business - they are, as Hartley has it, 'sites of knowledge-production and meaning-exchange' (1999: 6). New media activism such as a virtual sit-in 
campaign involves the exercise of symbolic power — the creation and distribution of symbolic content; the exchange of shaped information; the expression of cultural skills and values; advocacy, rhetoric, appeal and persuasion.

Symbolic power is not separate from other forms of power, but bound up with them - political power generates resources of symbolic power; economic power can be expressed as symbolic power; coercive power can be demonstrated through the exercise of symbolic power. Not everyone is able to exercise this power in the same kinds of way or with the same kinds of success. Certain types of institution, and certain individuals, have greater resources than others - schools and universities; churches, temples and mosques; and media organizations. These are the main centres of symbolic power — and each, as Hartley argues $(1998,1999)$, is built around teaching, a positive activity. ECD is one set of practices in which media, politics and pedagogy can be seen to converge.

But all kinds of teaching are messy — and the difference between what gets taught and what gets learned can be a big one. The exercise of symbolic power is not a simple, one-way transaction - like all forms of power, it is expressed within relationships, and so is not entirely predictable; it is, as Foucault has it, 'exercised from innumerable points, in the interplay of nonegalitarian and mobile relations' (1978: 94). Communicative acts can be interpreted in different ways. In the contemporary mediascape, communication is a dynamic process - even, in some accounts, a chaotic one (McNair 2006). 
ECD is not implicated in economic power (it does not produce or exploit transformative capacity). It is not implicated in political power (there is no exercise of legal authority or legislative capacity, no coordination or regulation of populations). And above all it is not implicated in coercive power (there is no exercise of force, legitimate or otherwise). ECD is instead within the domain of symbolic power. What is at stake here is a persistent reframing of ECD as coercive, whether as hacking, netwar or terrorism. Each of these misrecognises the practice of ECD and so works to delegitimize its practitioners.

\section{Electronic Civil Disobedience}

Electronic civil disobedience was first proposed in 1994 by Critical Art Ensemble (CAE) a small group of digital theorists and artists (http: / / www.critical-art.net). In their definition, electronic civil disobedience was 'hacking that is done primarily as a form of political resistance rather than as an idiosyncratic activity or as a profit- or prestige-generating process' (CAE interviewed in Little 1999: 194). The group's involvement with the AIDS activism of ACT UP in the 1980s had suggested to them that the established repertoire of protest gestures had lost their efficacy. Their response was to call for new alliances between hackers and activists, and for hacker actions against the cyberspace presence of institutions (CAE 1994, 1995).

In naming this proposed practice, CAE aligned the concept of electronic civil disobedience with the widely-understood principles of traditional civil 
disobedience, in a conscious attempt to draw legitimacy from the legacy of such figures as Thoreau (2000), Gandhi (2000) and Martin Luther King (2000). There were certain continuities with the established traditions of civil disobedience, such as the use of trespass and blockades as central tactics. However, there were also certain discontinuities, such as the de-emphasising of mass participation in favour of decentralised, cell-based organization, using small groups of from four to ten activists, and in particular the argument that electronic civil disobedience should be surreptitious, in the hacker tradition. Where practitioners of civil disobedience have been transparent about their opposition to the laws they break (Gandhi 2000: 410), CAE argued for a clandestine approach, proposing electronic civil disobedience as 'an underground activity that should be kept out of the public/popular sphere (as in the hacker tradition) and the eye of the media' (CAE 2001: 14).

The concept of electronic civil disobedience was developed further by the Electronic Disturbance Theater (EDT)

<http:/ / www.thing.net/ rdom/ ecd/ecd.html>, a four-person group founded by one-time CAE member Ricardo Dominguez. (There was friction between CAE and Dominguez, which seemed to centre around ownership of the concept of electronic civil disobedience and its history. See, for example, CAE 1998). The EDT moved away from CAE's emphasis on the clandestine exercise of elite hacker skills towards a more transparent public spectacle which aimed to draw as many participants together as possible (Wray 1998, Electrohippies Collective 2000). Denning (2001b: 72) suggests the first action of this kind was undertaken in protest at the French government's nuclear test 
policies in December 1995 by a group called the Strano Network. In this kind of prototype virtual sit-in, the 'flooding' effect was to be obtained simply by mobilising large numbers of people to visit the target site simultaneously and repeatedly reload/refresh the page (see also Jordan 2002: 123).

The EDT developed a piece of software called FloodNet, which both simplifies and automates such actions, which the EDT now labelled virtual sit-ins. Where CAE envisaged a small number of hackers with elite computer expertise, the EDT created a situation in which the more participants the better, and in which being able to click on a hyperlink was sufficient technical ability. The virtual sit-in enacts a simulation of a real-life physical gathering. As the Electrohippies, who organised a virtual sit-in as part of the Seattle WTO demonstrations in November 1999, put it, such actions: 'require the efforts of real people, taking part in their thousands simultaneously, to make the action effective. If there are not enough people supporting then the action doesn't work' (Electrohippies Collective 2000: unpaginated). Any legitimacy the action might have derives from the number of people it gathers. These actions, as Dominguez puts it, are about 'creating the unbearable weight of human beings in a digital way' (interviewed in Meikle 2002: 142).

The EDT initially developed the tactic to use in support of the Mexican Zapatistas, although FloodNet has been used in actions for a large number of other causes. In 2001, the Electrohippies staged an online action to coincide with the WTO meeting in Qatar (Jordan \& Taylor 2004: 41). On 20 June of the same year, activists targeted Lufthansa's Annual General Meeting, to protest about the airline's involvement in the forcible deportation of asylum seekers. 
As well as physical protests at the meeting itself, a virtual sit-in of the Lufthansa website was organised. While demonstrators in Cologne crowded the meeting venue, others around the world crowded the company's website in a what one observer terms: 'a hybrid of immaterial sabotage and digital demonstration' (Schneider 2002: 178). Other uses of the virtual sit-in tactic have targeted the US Republican National Committee, Dow Chemical, the Michigan State Legislature, and the infamous website of the Westboro Baptist Church of Topeka, Kansas at <http:/ / www.godhatesfags.com>.

The highest-profile use of the tactic to date was one in which the EDT were also key participants: the 1999 Toywar, in which an online toy retailer with the domain name <etoys.com>, registered in 1997, disputed the right of the pre-existing European art group etoy to use their own domain name <etoy.com>, registered in 1995. Legal action by the retailer was met with a sophisticated suite of tactical media responses, including a virtual sit-in of the toy store's website. The retailer capitulated in January 2000, two months before filing for bankruptcy (agent.NASDAQ 2001, Meikle 2002, Wishart \& Bochsler 2002, Wark 2003, Jordan \& Taylor 2004).

The central discourse here is that of tactical media (Bey 1991; Garcia \& Lovink 1997, 1999; CAE 2001; Lovink 2002; Boler 2008). While this, as one of its main proponents notes, is 'a deliberately slippery term' (Lovink 2002: 271), it emphasises the technological, the transitory and the collaborative. Tactical media mix subversive creativity and creative subversion. Tactical media projects are characterised by mobility and flexibility, by novelty and reinvention, and by a certain transient and temporary dimension - 'hit and 
run, draw and withdraw, code and delete', as Lovink and Schneider put it (2001: unpaginated).

While the virtual sit-in and the wider discourse of tactical media both emphasise novelty and re-invention, it is important to note that there are continuities here as well as transformations. On the one hand, the sit-in is a tactic with a long history. Sharp traces its uses as far back as 1838, and emphasises its association with the US Civil Rights movement and, before that, with Abolitionist campaigns (Sharp1973: 371-4); Ackerman and Du Vall document a successful use of the tactic against the Nazis in 1943 (2000: 237). Such history can offer pedagogical possibilities for Internet activists introducing virtual versions of familiar tactics. Yet at the same time, the virtual sit-in is significant in that it takes cyberspace as the actual site of action. In this sense, the virtual sit-in also represents a move towards using the technical properties of new media to formulate new tactics for effecting social change.

Such actions can be seen as vehicles for capturing the attention of the established news media, in order to force a cause onto the news agenda: activists can exploit the appetite for sensationalism (Vegh 2003: 92). However, there is a dilemma here for activists, in that while the news media are drawn to novelty and disruption, their coverage is also more likely to focus on that very novelty and disruption than on the underlying issues or causes involved, which may in fact work against the activist cause (Scalmer 2002: 41). This dilemma is especially pertinent in relation to the example of the virtual sit-in and its discourse of electronic civil disobedience. 


\section{Electronic Civil Disobedience and Hacktivism}

The practices of ECD are frequently subsumed under the discourse of 'hacktivism' (Denning 2001a, Jordan 2002, Vegh 2003, Jordan \& Taylor 2004, Gunkel 2005, Taylor 2005). For Denning: 'Hacktivism is the convergence of hacking with activism [...] Hacktivism includes electronic civil disobedience' (2001a: 263). 'Hacktivism', suggest Jordan and Taylor, 'is activism gone electronic' (2004: 1); it is 'a combination of grassroots political protest with computer hacking' and 'the emergence of popular political action $[\ldots]$ in cyberspace' (2004: 1).

In part, the discourse of hacktivism is an attempt to link ECD to the original discourse of the 'hacker ethic' (Levy 1984: 26-36). Taylor (2005) suggests that hacking had become the pursuit of technological mastery as an end in itself, whereas hacktivism introduced a new kind of political objective. If the EDT are hackers at all, it is in Levy's sense, which he applied to the innovators and designers of the early computer industry. Hacking, in Levy's description, was: 'a philosophy of sharing, openness, decentralization, and getting your hands on machines at any cost - to improve the machines, and to improve the world' (Levy 1984: ix). A 'hack' was an elegant solution to a technological problem; more than that, it had to be, as Levy says, 'imbued with innovation, style, and technical virtuosity' (1984: 10). In Levy's usage, hacking was about improving systems rather than crashing them; about sharing information rather than stealing or changing it. The early hackers made computer breakthroughs, not break-ins. 'The hacker', as Turkle put it, 'is a person 
outside the system who is never excluded by its rules' (1984: 208). The early hacker ethic, in Paul Taylor's analysis, had at its core three features: 'the ingenious use of any technology; the tendency to reverse engineer technology to do the opposite of its intended design; and the desire to explore systems' (Taylor 2005: 628). Or as cyberpunk science fiction novelist William Gibson observed, 'the street finds its own uses for things' (1986: 215). The Hacker Ethic persists in the Open Source software movement, and in related movements inspired by it, such as the Open Publishing models of the global Indymedia movement, and there have also been important restatements of this Hacker Ethic discourse (Himanen 2001, Wark 2004).

However, the discourse of 'hacking' has shifted radically in the more than two decades since Levy popularised the Hacker Ethic. Hackers have become, in Stanley Cohen's, term 'folk devils' (1972). The roots of this shift can be traced to the 1990 co-ordinated arrests and show trials in the US, Operation Sundevil (Sterling 1992, Jordan 1999). Sterling sees the real struggle in this and the early hacker show trials that followed as one over control of language: 'The real struggle was over the control of telco language, the control of telco knowledge. It was a struggle to defend the social "membrane of differentiation" that forms the wall of the telco community's ivory tower' (1992: 274). A struggle, in other words, over inclusion and exclusion, and over naming and control; a struggle expressed through and for symbolic power.

In this context, it becomes important to ask whether FloodNet is in fact hacking in any meaningful sense. EDT member Carmin Karasic points out that: 'FloodNet never accessed or destroyed any data, nor tampered with 
security, nor changed websites, nor crashed servers'

$<$ http:/ / www.pixelyze.com/scrapbook/index.htm>. If FloodNet does not make sense as hacking, therefore, is there anything at stake for the EDT in their implication within the hacktivism discourse? Hacking, after all, is something that many people would consider frightening, unfamiliar, criminal behaviour - the precise opposite of the connotations that the EDT see as advantages of using the term electronic civil disobedience. One conclusion to be drawn from this argument is that promoting an emergent cyberspatial politics as 'hacktivism' means dealing with the baggage of the 'hack' component of the term. This term may make it all too easy for electronic civil disobedience to be marginalised and demonised in turn. One challenge for activists, then, is not just to formulate new strategies and tactics appropriate to a shifting mediascape, but to recognise the ongoing need to create a careful vocabulary for discussing those tactics and strategies.

\section{Electronic Civil Disobedience and Netwar}

On 31 October 1998, the New York Times declared on its front page that the Electronic Disturbance Theater had declared 'netwar' on the Mexican

government. From some angles, this would appear to be a good result for the group in publicity terms. Vegh, for example, contends that 'While the U.S. mainstream media are in the hands of the corporate world, the sensationalist nature of hacktivism works to the activists' advantage' (2003: 92). However, the New York Times example, with its media declaration of 'netwar', points to how the practices of ECD can be framed within military discourses. Central to 
this is the discourse of netwar (Arquilla \& Ronfeldt 1997, 2001a, 2001b, 2001c; Arquilla 1998; Arquilla et al 1998):

Netwar refers to information-related conflict at a grand level between nations or societies. It means trying to disrupt, damage, or modify what a target population "knows" or thinks it knows about itself and the world around it. A netwar may focus on public or elite opinion, or both. It may involve public diplomacy measures, propaganda and psychological campaigns, political and cultural subversion, deception of or interference with local media, infiltration of computer networks and databases, and efforts to promote a dissident or opposition movements [sic] across computer networks (Arquilla \& Ronfeldt 1997: 28).

Arquilla and Ronfeldt's emphasis in this definition on information, opinion, diplomacy and propaganda identifies the concept as one within the domain of symbolic power relations. However, their choice of 'war' as the key term and discursive framework implies a coercive dimension which is in fact absent from the practice of ECD.

An essential component of the netwar concept is the use of network forms of organization:

The [information] revolution is favoring and strengthening network forms of organization, often giving them an advantage of hierarchical forms. The rise of networks means that power is migrating to nonstate actors, because they are able to organize into sprawling multiorganizational networks [...] more readily than can traditional, hierarchical, state actors. This means that conflicts may 
increasingly be waged by "networks", perhaps more than by "hierarchies". It also means that whoever masters the network form stands to gain the advantage (Arquilla \& Ronfeldt 2001a: 1).

A key tactic of such netwar practice is swarming: 'a seemingly amorphous, but deliberately structured, co-ordinated, strategic way to strike from all directions at a particular point or points' (Arquilla \& Ronfeldt 2001a: 12). This is the principle underlying the tactic of the virtual sit-in. Swarming is a concept which has to some extent been popularised in Howard Rheingold's analogous concept of 'smart mobs'. Smart mobs, writes Rheingold, 'consist of people who are able to act in concert even if they don't know each other' (2002: xii). The role of mobile communications in connecting and coordinating the crowds that forced the ouster of Philippines President Joseph Estrada in January 2001 is one example (Goggin 2006, Rafael 2006). Others would include the various so-called anti-globalisation protests in Seattle, Prague, Melbourne, Genoa and elsewhere (Electrohippies Collective 2000, de Armond 2001, Meikle 2002, Jordan \& Taylor 2004, Kahn \& Kellner 2004), or the monthly 'organized coincidence' that is Critical Mass, with its regular coordinated bike rides by transport activists in cities around the world.

Arquilla has described the virtual sit-in as a harbinger of more widespread and effective tactics, framing it explicitly in terms of military discourse: 'FloodNet is the info age equivalent of the first sticks of bombs dropped from slow-moving Zeppelins in the Great War [...] The implication, of course, is that netwar will evolve, as air war did, growing greatly in effect over time' (Arquilla interviewed in Meikle 2002: 157). A central question, however, is whether such events are best described using terms built around the 
vocabulary of warfare. The RAND analysts have acknowledged, for instance, that what they term 'social netwars' may in fact have 'some positive consequences, especially for spurring social and political reforms' (Arquilla et al 1998: 120). Given this point, and the participation of such groups as the Red Cross and the Catholic church in the Zapatista support campaigns, it can be contended that there is something problematic about the 'war' component of the term 'netwar'. Why not, for example, 'netpeace'? It is important to emphasise that ECD was framed from the beginning by its theorists as a nonviolent concept. For example, ECD, wrote CAE, is 'a nonviolent activity by its very nature, since the oppositional forces never physically confront one another' (1995: 18). There is something problematic about this militarisation of humanitarian actions: specifically, the connotations of netwar tend to demonise non-state actors while legitimising state actors and actions. It is a vivid illustration of a struggle expressed over and through the exercise of symbolic power.

\section{Electronic Civil Disobedience and Terrorism}

The third discourse under which ECD is often subsumed is that of terrorism. For example, one survey of Internet politics includes a brief account of the EDT and FloodNet in a chapter on 'criminal activity in cyberspace', which concludes that cyberspace 'needs to be safeguarded against terrorist attacks' (Margolis \& Resnick 2000: 202). Terrorism analyst Bruce Hoffman also discusse ECD in a terrorism frame, quoting a human rights activist from an established NGO under the sub-heading 'Terrorist and Insurgent Use of the Internet' (2006: 201), and implying a link between electronic civil 
disobedience in support of the Zapatistas and the use of the Internet by terrorist groups (2006: 204). One content analysis of US newspaper articles about hacking suggested that the discourse about hacking was increasingly blurred with that of cyberterrorism, with online protest activity represented as disruption, vandalism or worse (Vegh 2005).

In one of the most important examples of this linkage, the writings of computer security analyst Dorothy Denning repeatedly place activists, hacktivists and 'cyberterrorists' within the same analytical frame, suggesting that 'the boundaries between them are somewhat fuzzy' (2001a: 241) and that 'an individual can play all three roles' (2001a: 242). This is a problematic analysis, which yokes together disparate behaviours and practices in a hypothetical frame (Denning's discussion of cyberterrorism is entirely futureoriented). Denning's use of terms such as 'hacker warriors' and 'cyber warriors' blurs the line between non-violent symbolic protest, and coercive action. One essay (2001b) conflates activism and terrorism, writing of 'hacker warriors' who 'often initiate the use of aggression and needlessly attack civilian systems' (2001b: 70). In this discussion of cyberspace as 'digital battleground' (2001b: 75), the very real distinctions between symbolic political protest and coercive violence are elided. The potential consequences of all this for political activists are contained in a line from Denning's own work: 'the threat of cyberterrorism, combined with hacking threats in general, is influencing policy decisions related to cyber-defence at both a national and international level' (2001a: 288, emphasis added). 
It should be acknowledged that elsewhere Denning has emphasised the distinction between civil disobedience and terrorism: 'Both EDT and the Electrohippies view their operations as acts of civil disobedience, analogous to street protests and physical sit-ins, not as acts of violence or terrorism. This is an important distinction. Most activists [...] are not terrorists' (2000: unpaginated). It is indeed an important distinction, and Ricardo Dominguez has quoted this more than once in support of his own organization (Dominguez 2005, Kartenberg 2005). But by placing activists and non-violent protests within the same frame as terrorism, Denning undermines the distinction.

In September 1999, EDT member Stefan Wray made a presentation to the US National Security Agency. Wray pointed out that the event's program had renamed his group 'the Electronic Disruption Theater' and described the Zapatistas as a 'sect'. While these could, of course, have been the result of simple errors, Wray argued that they may also have represented what he termed 'an attempt to recategorize who we are into a framework that is understandable to the national security minds' (1999b). This is not a trivial issue: the ways in which actions are framed and described, the motives attributed, meanings sought and implied, are a fundamental symbolic power struggle. For example, as Schlesinger, Murdock and Elliott have argued in relation to definitions of terrorism: 'Contests over definitions are not just word games. Real political outcomes are at stake. [...] Language matters, and how the media use language matters' (Schlesinger, Murdock \& Elliott 1983: 1). 
The most sobering relevant example of the dangers of allowing symbolic protest to be conflated with terrorism is the case of Steve Kurtz of Critical Art Ensemble, the group who initiated the discourse of electronic civil disobedience. In May 2004 Kurtz was detained by FBI agents on suspicion of 'bioterrorism'. Agents seized lab material used in CAE's art works about genetic modification, as well as their writings, and initially sought to bring charges relating to biological weaponry. Although it became clear that the materials were harmless and readily obtainable by anyone, and moreover had been used in legitimate art works at public galleries, the investigation was not dropped and the charges were changed to allegations of 'mail fraud' and 'wire fraud', revolving around technical details of how Kurtz obtained some of the material, worth $\$ 256$, from his co-accused Professor Robert Ferrell. At the time of writing in January 2008, Kurtz and Ferrell face potential prison sentences of twenty years, in a precedent-setting conflation of art criticism and 'terrorist' scare-mongering $<$ http: / / caedefensefund.org $>$.

ECD can be distinguished from terrorism insofar as the practice of terrorism is coercive (although its discourse may also be symbolic). In the case of ECD, both practice and discourse are symbolic. This point is developed below in the final section of this essay.

\section{Conclusion}

In what ways is electronic civil disobedience implicated in symbolic power?

We can distinguish between the practice of ECD and the discourse of ECD. The practice of ECD involves publicising and promoting actions, such as 
virtual sit-ins. This usually involves distributing information through email lists and websites, although it has also involved participation in art events, academic conferences, and gatherings of hackers or security personnel, as well as giving frequent interviews to journalists, academics, other writers, broadcasters and film-makers. The practice of ECD involves the carrying out of actions which are on one level simulations and are partly rhetorical. FloodNet does not crash or immobilise servers: it enables a simulation of a physical gathering in order to draw attention to a cause. And the practice of ECD involves exploiting this attention - particularly the attention of the established media, and any subsequent discussion of the action or, more rarely, the cause in support of which the action was held. The discourse of ECD involves the invoking of high-value historical antecedents from the civil disobedience tradition, such as Gandhi or Thoreau. But it also involves problematic involvements with the discourses of hacktivism, netwar and terrorism, as well as a dispute over 'ownership' of the concept between CAE and EDT. In both the practice and the discourse of ECD, all of these key aspects revolve around claim and counter-claim, around rhetoric and persuasion, within the arena of symbolic power relations. If legitimate forms of nonviolent online protest are to continue, they should be recognised as manifestations not of coercive violence or force, but of symbolic power.

\section{References}

Ackerman, Peter \& Du Vall, Jack (2000) A Force More Powerful: A Century of Nonviolent Conflict, Basingstoke: Palgrave Macmillan. 
agent.NASDAQ (aka Reinhold Grether) (2001) 'How The Etoy Campaign Was Won: an Agent's Report', in Peter Weibel \& Timothy Druckrey (eds), net_condition: art and global media, Cambridge, MA: MIT Press, pp. 280-5.

Arquilla, John (1998) 'The Great Cyberwar of 2002', Wired 6.02, February, <http:/ / www.wired.com/wired/archive/6.02/ cyberwar.html>, accessed 10 January 2008.

_ \& Ronfeldt, David (1997) [1993] 'Cyberwar is Coming!' in John Arquilla \& David Ronfeldt (eds) In Athena's Camp: Preparing for Conflict in the Information Age, Santa Monica, CA: RAND Corporation, pp. 23-60, <http:/ / www.rand.org/ publications / MR/MR880>, accessed 10 January 2008.

_ (2001a) 'The Advent of Netwar (Revisited)' in John Arquilla \& David Ronfeldt (eds) Networks and Netwars: The Future of Terror, Crime, and Militancy, Santa Monica, CA: RAND Corporation, pp. 1-25, <http:/ / www.rand.org/pubs/monograph_reports/MR1382>, accessed 10 January 2008.

— (2001b) 'Fighting the Network War', Wired 9.12, December, <http:/ / www.wired.com/wired/archive/9.12/ netwar.html>, accessed 10 January 2008.

- (eds) (2001c) Networks and Netwars: The Future of Terror, Crime, and Militancy, Santa Monica, CA: RAND Corporation, 
<http:/ / www.rand.org/pubs/monograph_reports/MR1382>, accessed 10 January 2008.

_ \& Fuller, Graham F., \& Fuller, Melissa (1998) The Zapatista 'Social Netwar' in Mexico, Santa Monica, CA: RAND Corporation, <http:/ / www.rand.org/publications / MR/MR994>, accessed 10 January 2008.

Bey, Hakim (1991) T.A.Z.: the Temporary Autonomous Zone, Ontological Anarchy, Poetic Terrorism, New York: Autonomedia.

Boler, Megan (ed.) (2008) Digital Media and Democracy: Tactics in Hard Times, Cambridge, MA: MIT Press.

Bourdieu, Pierre (1991) Language and Symbolic Power, Cambridge: Polity.

Carey, James (1989) Communication as Culture, New York: Routledge.

Castells, Manuel (2007) 'Communication, Power and Counter-Power in the Network Society', International Journal of Communication, vol. 1, no. 1, pp. 23866.

Cohen, Stanley (1972) Folk Devils and Moral Panics: the Creation of the Mods and Rockers, London: MacGibbon \& Kee.

Couldry, Nick (2000) The Place of Media Power, London: Routledge. 
(2003) Media Rituals, London: Routledge.

Critical Art Ensemble (1994) The Electronic Disturbance, New York: Autonomedia.

_ (1995) Electronic Civil Disobedience and Other Unpopular Ideas, New York: Autonomedia.

_ (1998) 'An Open Letter to Ricardo Dominguez', posted to the Nettime list, 28 September. Archived at <http: / / www.nettime.org/ListsArchives / nettime-1-9809/msg00154.html>, accessed 10 January 2008.

- (2001) Digital Resistance: Explorations in Tactical Media, New York: Autonomedia.

De Armond, Paul (2001) 'Netwar in the Emerald City: WTO Protest Strategy and Tactics', in John Arquilla \& David Ronfeldt (eds) Networks and Netwars: The Future of Terror, Crime, and Militancy, Santa Monica, CA: RAND Corporation, pp. 201-35,

<http:/ / www.rand.org/pubs/monograph_reports/MR1382>, accessed 10 January 2008.

Denning, Dorothy E. (2000) ‘Cyberterrorism: Testimony Before the Special Oversight Panel on Terrorism Committee on Armed Services, U.S. House of Representatives', 23 May, 
$<\mathrm{http}$ // www.cs.georgetown.edu/ denning/infosec/ cyberterror.html>, accessed 10 January 2008.

_ (2001a) [1999] 'Activism, Hacktivism, and Cyberterrorism: The Internet as a Tool for Influencing Foreign Policy', in John Arquilla \& David Ronfeldt (eds) Networks and Netwars: The Future of Terror, Crime, and Militancy, Santa Monica, CA: RAND Corporation, pp. 239-88, $<$ http:/ / www.rand.org/pubs/monograph_reports/MR1382>, accessed 10 January 2008.

— (2001b) 'Cyberwarriors: Activists and Terrorists Turn to Cyberspace', Harvard International Review, vol. 23, no. 2, pp. 70-5.

Dominguez, Ricardo (2005) ‘SWARM the Minutemen — Post Action Update May 30th, 2005', posted to the Nettime list, 31 May. Archived at <http:/ / www.nettime.org/Lists-Archives/nettime-1-0505/msg00071.html>, accessed 10 January 2008.

Electrohippies Collective (2000) ‘Client-side Distributed Denial-of-Service: Valid Campaign Tactic or Terrorist Act?', Electrohippies Occasional Paper No.1, $<$ http://www.fraw.org.uk/download/ehippies/op-01.html>, accessed 10 January 2008.

Foucault, Michel (1978) The Will to Knowledge: The History of Sexuality Volume 1, London: Penguin. 
Gandhi, Mohandas K. (2000) [1920] 'A Selection From His Writings', in Paul Lauter (ed.) Walden and Civil Disobedience, Boston: Houghton Mifflin, pp. 40722.

Garcia, David and Lovink, Geert (1997) 'The ABC of Tactical Media', posted to the Nettime list, 16 May. Archived at <http: / / www.nettime.org/ListsArchives / nettime-1-9705/msg00096.html>, accessed 10 January 2008.

_ (1999) 'The DEF of Tactical Media', posted to the Nettime list, 22 February. Archived at <http: / / www.nettime.org/Lists-Archives / nettime-19902/msg00104.html>, accessed 10 January 2008.

Gibson, William (1986) ‘Burning Chrome', collected in (1995) Burning Chrome and Other Stories, London: HarperCollins.

Goggin, Gerard (2006) Cell Phone Culture, London: Routledge.

Gunkel, David J. (2005) 'Editorial: Introduction to Hacking and Hacktivism', New Media E Society, vol. 7, no. 5, pp. 595-97.

Hartley, John (1998) 'Juvenation: News, Girls and Power' in Cynthia Carter, Gill Branston and Stuart Allan (eds) News, Gender and Power, London: Routledge, pp. 47-70.

_ (1999) Uses Of Television, London: Routledge. 
Himanen, Pekka (2001) The Hacker Ethic, New York: Random House.

Hoffman, Bruce (2006) Inside Terrorism (revised edition), New York: Columbia University Press.

Jordan, Tim (1999) ‘New Space, New Politics: The Electronic Frontier

Foundation and the Definition of Cyberpolitics' in Tim Jordan (ed.) Storming the Millennium: The New Politics of Change, London: Lawrence \& Wishart, pp. 80-107.

- (2002) Activism! Direct Action, Hacktivism and the Future of Society,

London: Reaktion Books.

_ (2007) ‘Online Direct Action: Hacktivism and Radical Democracy’ in Lincoln Dahlberg and Eugenia Siapera (eds) Radical Democracy and the Internet, Basingstoke: Palgrave Macmillan, pp. 73-88.

_ \& Taylor, Paul (2004) Hacktivism and Cyberwars: Rebels With a Cause, London: Routledge.

Kahn, Richard and Kellner, Douglas (2004) `New Media and Internet Activism: From the "Battle of Seattle" to Blogging', New Media E Society, vol. 6, no. 1, pp. 87-95. 
Karasic, Carmin (n. d.) 'Electronic Disturbance Theater and FloodNet

Scrapbook', <http:/ / www.pixelyze.com/scrapbook/index.htm>, accessed 10 January 2008

Kartenberg, Hans Peter (2005) 'A Transparent and Civil Act of Disobedience.', <http:/ / post.thing.net/ node/304>, accessed 10 January 2008.

King, Martin Luther (2000) [1962] 'A Legacy of Creative Protest', in Paul Lauter (ed.), Walden and Civil Disobedience, Boston: Houghton Mifflin, p. 433.

— (2000) [1958] "From Stride Toward Freedom", in Paul Lauter (ed.),

Walden and Civil Disobedience, Boston: Houghton Mifflin, pp. 422-32.

Levy, Steven (1984) Hackers: Heroes of the Computer Revolution, New York: Anchor Press/Doubleday.

Little, Mark (1999) 'Practical Anarchy: an Interview with Critical Art Ensemble', Angelaki, vol. 4, no. 2, pp. 192-201.

Lovink, Geert (2002) Dark Fiber: Tracking Critical Internet Culture, Cambridge, MA: MIT Press.

— \& Schneider, Florian (2001) 'New Rules of the New Actonomy', posted to the Nettime list, 25 June. Archived at $<$ http:/ / amsterdam.nettime.org/Lists-Archives / nettime-10106/msg00114.html>, accessed 10 January 2008. 
Manion, Mark and Goodrum, Abby (2000) 'Terrorism or Civil Disobedience:

Toward a Hacktivist Ethic', Computers and Society, June, pp. 14-19.

Margolis, Michael and Resnick, David (2000) Politics as Usual: The Cyberspace 'Revolution', Thousand Oaks, CA: Sage.

McNair, Brian (2006) Cultural Chaos: Journalism, News and Power in a Globalised World, London: Routledge.

Meikle, Graham (2002) Future Active: Media Activism and the Internet, New York: Routledge.

Melucci, Alberto (1996) Challenging Codes: Collective Action in the Information Age, Cambridge: Cambridge University Press.

Rafael, Vicente L. (2006) [2003] 'The Cell Phone and the Crowd: Messianic Politics in the Contemporary Philippines' in Wendy Hui Kyong Chun and Thomas Keenan (eds) New Media Old Media: A History and Theory Reader, New York: Routledge, pp. 297-313.

Rheingold, Howard (2002) Smart Mobs: the Next Social Revolution, Cambridge, MA: Basic Books.

Scalmer, Sean (2002) Dissent Events: Protest, the Media and the Political Gimmick in Australia, Sydney: UNSW Press. 
Schlesinger, Philip, Murdock, Graham and Elliott, Philip (1983) Televising

'Terrorism': Political Violence in Popular Culture, London: Comedia.

Schneider, Florian (2002) 'Virtual Sabotage', in Eveline Lubbers (ed.) Battling

Big Business: Countering Greenwash, Infiltration and Other Forms of Corporate Bullying, Melbourne: Scribe Publications, pp. 177-80.

Sharp, Gene (1973) The Politics of Nonviolent Action (in 3 volumes), Boston: Porter Sargent.

Sterling, Bruce (1992) The Hacker Crackdown, London: Viking.

Taylor, Paul A. (2005) ‘From Hackers to Hacktivists: Speed Bumps on the Global Superhighway?', New Media \& Society, vol. 7, no. 5, pp. 625-46.

Thompson, John (1995) The Media and Modernity, Cambridge: Polity.

Thoreau, Henry David (2000) [1849; 1866] 'Civil Disobedience', in Paul Lauter (ed.) Walden and Civil Disobedience, Boston: Houghton Mifflin, pp. 17-36.

Turkle, Sherry (1984) The Second Self, Cambridge, MA: MIT Press.

Vegh, Sandor (2003) 'Classifying Forms of Online Activism: the Case of Cyberprotests Against the World Bank', in Martha McCaughey \& Michael D. 
Ayers (eds) Cyberactivism: Online Activism in Theory and Practice, New York: Routledge, pp. 71-95.

_ (2005) ‘The Media's Portrayal of Hacking, Hackers, and Hacktivism Before and After September 11', First Monday, vol. 10, no. 2, <http:/ / firstmonday.org/issues / issue10_2/vegh/index.html>accessed 10 January 2008.

Wark, McKenzie (2003) 'Toywars: Conceptual Art Meets Conceptual

Business', M/C Journal, vol. 6, no. 3, <http:/ / journal.mediaculture.org.au/0306/02-toywars.php>, accessed 10 January 2008.

Wishart, Adam and Bochsler, Regula (2002) Leaving Reality Behind, London: Fourth Estate.

Wray, Stefan (1998) 'On Electronic Civil Disobedience', <http: / / www.thing.net/ rdom/ ecd/ oecd.html>, accessed 10 January 2008.

_ (1999) 'The National Security Agency Performance', <http:/ / www.thing.net/ rdom/ecd/nsa_show1.html>, accessed 10 January 2008.

\section{Bio}


Graham Meikle is the author of Interpreting News (Palgrave Macmillan 2008) and Future Active: Media Activism and the Internet (Routledge 2002). He lectures in the Department of Film, Media \& Journalism at Stirling University in Scotland. 